DOI $10.23859 / 2587-8352-2018-2-2-1$

UDC 94(430)

Tatiana Evdokimova

Doctor of Historical Sciences, Professor

Volgograd State Socio-Pedagogical University

(Volgograd, Russia)

eva_tan@mail.ru

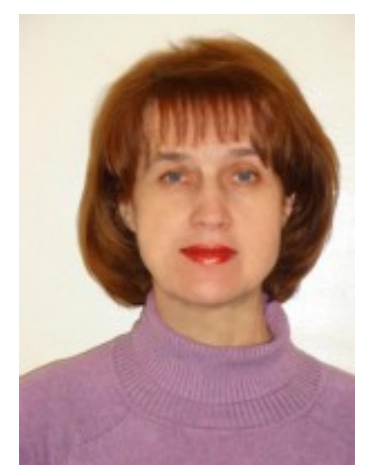

\title{
Walter Rathenau - a man ahead of time
}

Abstract. The contradictory personality of Walter Rathenau is considered, which is underinvestigated in the domestic historiography, from the perspective of a comprehensive analysis of his versatile life activity and creative written heritage. Attention is drawn to the ability of Rathenau to go beyond the visible phenomena and processes and predict the future. The feasibility of his several ideas, confirmed by the practice of the $20^{\text {th }}$ and $21^{\text {st }}$ centuries, is emphasized in the article.

Keywords: Walter Rathenau, the German Empire, the Weimar Republic, contradictory personality, systemic thinking, modern problems.

\section{Introduction}

In his diary Walter Rathenau wrote, "What a tasty morsel I will be for privatdozents in $1950 "$ ". At the end of last year, the world celebrated the $150^{\text {th }}$ anniversary of Walther Rathenau, but the interest to his personality is not growing thin. However, one cannot call it steady.

In the years of the Weimar Republic, according to the contemporary and later German researcher Sebastian Haffner, Walter Rathenau was rated amongst five or six most popular personalities. Whereby, Haffner noted the tremendous force of influence of W. Rathenau's 'personal magic' upon young people ${ }^{2}$.

\footnotetext{
${ }^{1}$ Rathenau W. Tagebuch 1907-1922. Düsseldorf, 1929, S. 159.

2 Haffner S. a German's Biography. Available at: https://unotices.com/book.php?id= 83456\&page $=8$ (retrieved: 25.01.2018); Haffner S. Die Erinnerungen 1914-1933. Geschichte eines Deutschen. Deutsch. Stuttgart; München, 2001, S. 50-51.
} 
Research

In modern Germany, the most known Weimar politicians are Chancellor Heinrich Brüning and foreign minister Gustav Stresemann. Walther Rathenau's name hardly means anything to most of German youth, except for the students of the schools named after him ${ }^{3}$. As the 'Allgemeine Zeitung' rightly noted, "today, in the everyday life, one can find the streets and squares named after Rathenau. The Treaty in Rapallo might be remembered. That is at best. But ... most of his life is unknown" ${ }^{4}$.

The first studies on Walter Rathenau, which were of publicist nature, appeared in Germany during his lifetime; the first theses - literally 1.5-2 years after his assassination. However, by the beginning of the $21^{\text {st }}$ century, only 35 dissertations had been published in Germany ${ }^{5}$. If one is to analyze the German historiography related to the study of Walter Rathenau's life and his written legacy, one can identify a certain trend. The surge of interest and appeal to his work was observed when the German society and the state were looking for a response to the challenge of the time: be it the search for the ways of developing Germany under the conditions of the first democracy, the new methods for overcoming the economic crisis or building the way for international cooperation ${ }^{6}$.

In the national science of the Soviet period, the appeal to the personality of Walter Rathenau was related to his initiation of the Rapallo Treaty of 1922 (A.A. Akh$\operatorname{tamzian}^{7}$ ). Since the 1990s, the subject of research for the national historians included such spheres of Walter Rathenau's activity as his socio-economic and political views of the concept (A.V. Molodchik ${ }^{8}$ ), modeling his ideas about Russia (B.I. Grekov'),

${ }^{3}$ Gedenklauf für Walther Rathenau. Available at: https://www.lr-online.de/lausitz/senftenberg/ gedenklauf-fuer-walther-rathenau_aid-3707586; Walther-Rathenau-Schule. Gymnasium. Available at: https://www.wrs-berlin.de.(retrieved: 25.01.2018)

${ }^{4}$ Walther Rathenau - Symbolfigur der Republik. Allgemeine Zeitung. 23.09.2017. Available at: http://www.allgemeine-zeitung.de/vermischtes/leben-und-wissen/walther-rathenau-symbolfigurder-republik_18199565.htm. (retrieved: 25.01.2018)

${ }^{5}$ Beek J. van. Walther Rathenau (1867-1922). Die Mission eines unverstandenen deutschjüdischen Europäers. S. 2. Available at: www.beacruisesyeah.live/beuker/geschichte/texte_hefte/ Rathenaubuch.pdf 133 S. (retrieved: 25.01.2018)

${ }^{6}$ Schulin E. Walter Rathenau. Repräsentant, Kritiker und Opfer seiner Zeit. Göttingen; Zürich. 1992; Brenner W. Walther Rathenau. Deutscher und Jude. München. 2005; Hentzschel-Fröhlings J. Walther Rathenau als Politiker der Weimarer Republik. Husum, 2007; Schölzel C. Walther Rathenau. Eine Biographie. Paderborn, 2006; Volkov S. Ein jüdisches Leben in Deutschland 1867 bis 1922. München, 2012 u.a.

${ }^{7}$ Akhtamzian A. Rapall'skaia politika. Sovetsko-germanskie diplomaticheskie otnosheniia v 1922-1932 gg. [Rapallo Politics. Soviet-German Diplomatic Relations in 1922-1932]. Moscow, 1974.

${ }^{8}$ Molodchik A.B. Sotsial'no-ekonomicheskie i politicheskie vzgliady i kontseptsii V. Ratenau: published summary of dissertation [Socio-economic and Political Views and Concepts V. Rathenau]. Perm, 2001. 
his description as the ideologist of a social state (G.M. Sadovaia ${ }^{10}$ ). The first generalizing work studying Rathenau's activities, views and ideas was written by T.I. Lypka ${ }^{11}$. If one is to summarize the activation of scientific interest in the life and creative work of Rathenau in Russia, we would say that it was conditioned by the same reasons as in Germany: the search for answers to the questions of modern development of the state, society and man in general.

\section{Main body}

The 'amphibian man" ${ }^{12}$ is one of the typical characteristics of Walter Rathenau, attesting to the fact that he was an extremely contradictory personality, combining difficult or even incompatible personality traits.

The origins of this phenomenon should be sought in his childhood, when he, according to his own testimony, combined the sublime nature of his mother and the pragmatism of his father. Walther Rathenau wrote about himself in the following way, "My nature, in ridiculous stubbornness and virtue of kindness, had mixed in me both sources of the old blood, which led to the inevitable contradiction: the propensity for the real and the craving for the spiritual. Walther's mother, Matilda Rathenau, who came from the medieval Jewish family Liebermann, introduced her son to the artworld of fine art, music, European culture and languages (he spoke English, French and Italian). Rathenau's father, Emil Rathenau, was the founder of $A E G$ and the owner of the largest electric company. The circle of contacts centered around the machine factory in Berlin, whereas the world view was reduced to the latest technological achievements. His father's domination in the family distanced Walther from him for a long time and brought him closer to his mother. It is thought that through the whole of conscious experience, even when he would take most important posts, Rathenau would strive to realize his cherished desire, expressed in the children's

${ }^{9}$ Grekov B.I. Val’ter Ratenau i Rossiia: evoliutsiia vneshnepoliticheskikh vzgliadov 19141922 [Walter Ratenau and Russia: The evolution of foreign policy views 1914-1922]. Pervaia mirovaia voina: diskussionnye problemy istoriiu [World War I: Controversial Issues in History]. Moscow, 1994, pp. 102-113.

${ }^{10}$ Sadovaia G.M. Germaniia: ot kaizerovskoi imperii k demokraticheskoi respublike (19141922 gg.) [Germany: from the German (Kaiser) Empire to the German Democratic Republic (1914-1922)]. Samara, 2008.

${ }^{11}$ Lypka T.I. Val'ter Ratenau i ego vremia: lichnost'v ekonomicheskoi, politicheskoi i intellektual'noi istorii Germanii kontsa XIX-pervoi treti XXv. [Walter Rathenau and his Time: A Person in the Economic, Political and Intellectual History of Germany at the end of the $19^{\text {th }}$ - first third of the $20^{\text {th }}$ century]. Kirov, 2008.

${ }^{12}$ Beek J. van. Walther Rathenau (1867-1922). Die Mission eines unverstandenen deutschjüdischen Europäers. S. 10. Available at: www.beacruisesyeah.live/beuker/geschichte/texte _hefte/ Rathenaubuch.pdf 133 S. (retrieved: 25.01.2018). 
Research

poem devoted to his mother's birthday: “... I want to do everything to make you happy with me"13.

Walter Rathenau graduated from the Wilhelm-Gymnasium, named after German Emperors Wilhelm I and Wilhelm II, and continued his studies - after a painful choice and pressure from his father - at the universities of Strasbourg, Berlin, Munich, studying chemistry, physics and mathematics, which, from his parent's point of view, were "the foundation of modern science and technology". At the same time, he was writing plays, publishing articles under the name of Hartenau, implementing his need for the internal freedom, which, in his opinion, was higher than prosperity. To the suggestion of his mother to become a professor, he replied, "And what is then? The professorship with all its mercantile spirit, human worship and evil tongue would put me to death" $"$.

Walther Rathenau was long considered the heir to his father, Emil Rathenau, the continuer of the $A E G$ business (German: 'General Electricity Company'). However, in the end, the multi-sided personality was formed. "Industrialists have long known Walther Rathenau as a supervisory board member at almost hundreds of enterprises, bankers knew him as the director of a trading firm, sociologists - as the author of ambitious and original books, courtiers - as the confidant of the Kaiser, colonies - as an expert who accompanied Dernburg, the military - as the head of the German raw materials department, the patent office - as the applicant for several patents in the chemical industry, writers - as the 'brother of the quill'; the director of the theater after Rathenau's death found his drama, lying dusty in the cabinet of his office ${ }^{15}$. The scope of Walter Rathenau's interests, who was the nephew of the artist Max Liebermann, was exceedingly wide: he bought paintings of Expressionist artists Edvard Munch and Max Pechstein; met the writers Frank Wedekind, Hugo von Hofmannstahl, Gerhart Hauptmann; provided financial support to the theatre director Max Reinhard ${ }^{16}$. His open-mindedness and the variety of activities contributed to shaping personality of encyclopedic knowledge. The world of financiers and the world of spiritual strength constituted a whole for him.

The contrariety of nature for Walther Rathenau was not only conditioned by the polar opposed influence of his parents and the nature of his activities, but rather also

${ }^{13}$ Rathenau W. Neue Briefe. Dresden, 1927, S. 9.

${ }^{14}$ Beek J. van. Walther Rathenau (1867-1922). Die Mission eines unverstandenen deutschjüdischen Europäers. S. 21.

${ }^{15}$ Zweig S. Walter Rathenau. LEKHAIM OKTIABR' 1999 KHESHVON 5760-10 (90) [LECHAIM OCTOBER 1999 HESHVON5760-10 (90)]. Available at: https://lechaim.ru/ARHIV/90/ cveyg.htm. (retrieved: 25.01.2018).

16 Sontheimer M. Blitzende Gedankenfülle. Spiegel 25.09.12. Available at: http://www.spiegel.de/ spiegel /spiegelgeschichte/d-88536750.html (retrieved: 25.01.2018) 
by the shaping of his personality under the conditions of a challenging search for selfidentification, when he was torn between the self-esteem and self-hatred ${ }^{17}$. It was difficult for Rathenau to understand that he was a second-rate burgher: his family members were typical representatives-intellectuals of Jewish assimilation in Germany ${ }^{18}$. Suffering as Jewish identity, Rathenau wrote 'Hear, O Israel!' (1897), where he called his compatriots "an Asian horde", "a foreign organism within the German nation" ${ }^{\prime 19}$. Although many German Jews despised the Eastern European Jews, the reaction of the society was highly negative. Later he distanced himself from this activity and tried to find his place amongst the German society both for himself and his comrades. He called on the state and all its citizens, including the Jews, to work together for the benefit of the whole society. Under the influence of Gobineau, he determined the races; however, when he saw that it led to anti-Semitism, nationalism and racism, he distanced himself from the definition.

On the other hand, Rathenau openly declared his Jewishness, as he was proud of his descent from the Jewish patrician family, that, from his point of view, endowed him with elite consciousness and a sense of superiority. Rathenau compared himself to the great Jewish prophet, whereby claiming that only faith without dogmas created space to preach Christ. He refused to be christened, although he realized ${ }^{20}$ that the conversion to Protestantism would open the way for him to other posts ${ }^{21}$. (As, for example, was the situation with his closest friend, Maximilian Harden, in the German Kaiser's Empire). In Rathenau's invincible belief, "even if half of the Israelites 'tribe' changed their faith, this would lead to nothing but furious anti-Semitism against the converts. When he was offered the post of foreign minister of Germany's Weimar Republic, Rathenau, in response to the rhetoric that a Jew could not assume this post, compared himself to Disraeli. He said he would demolish the barriers by means of which the anti-Semites wanted to isolate the Jews." "And why cannot he do the same as Disraeli did?"22 He saw one goal - to be necessary to Germany.

${ }^{17}$ Rozhanskii L. "I want to declare immediately and openly that I am a Jew ...". Cascade. $22^{\text {nd }}$ November 2012. Available at: http://kackad.com/kackad. (retrieved: 25.01.2018); Volkov S. Ein jüdisches Leben in Deutschland 1867 bis 1922. München, 2012.

${ }^{18}$ Brenner W. Walther Rathenau. Deutscher und Jude. Cover: Walther Rathenau. München, 2005.

${ }^{19}$ Rathenau W. „Höre, Israel!” (1897). Dokumente - Gesellschaft und Kultur. S. 1. Available at: http://ghdi.ghi-dc.org/sub_document.cfm?document_id=717\&language=german (retrieved: 25.01.2018.)

${ }^{20}$ Hentzschel-Fröhlings J. Walther Rathenau als Politiker der Weimarer Republik. Husum, 2007, S. 75.

${ }^{21}$ Craig G.F. Deutsche Staatskunst von Bismarck bis Adenauer. Düsseldorf, 1961, S. 71.

${ }^{22}$ Cit. from Hentzschel-Fröhlings J. Walther Rathenau als Politiker der Weimarer Republik, S. 80,81 . 
Research

But not only the family environment influenced the development of Walther Rathenau's personality. The end of the $19^{\text {th }}$-early $20^{\text {th }}$ century was the period of rapid economic growth in Germany, appearance of new industries, mass production and mass society, which had colossal consequences for one's inner world, internal freedom as an essential personality trait. The dualism manifested in the relations with his parents, with regards to their origin, occupation, found its continuation in contradictions between his ideas and activities; between his mind and soul. Walther Rathenau was both an idealist philosopher who tried to explain and regulate his inner life with the help of such concepts as instinct, soul, spirit, transcendence, and, on the other hand, he marched under the standards of facts, having received brilliant education in natural science and having defended a thesis in electrical engineering.

It was natural science and electrical engineering that helped him develop the systemic concepts of thinking. With their help, he learned to think not in a separate subsystem, but using a whole-of-system approach. He was interested in the theoretical foundations of natural science and engineering sciences to provide rationalization for systemic universal thoughts, extending them to the processes that took place in the economy, industry, banking system, politics and, finally, in the society. The foundation of this was laid at the factory in Bitterfeld, where Walther Rathenau first applied the principle for "connection of each element with the center".

The application of technical innovations had far-reaching consequences in all spheres of life. Technologies became a synonym for progress. In 1900, 800 thousand people lived in Germany: the birth rate increased and mortality rates fell, mainly due to improvement in housing conditions, hygiene and new technological advances introduced around the house and at work. In general, the standard of living rose.

However, the technical progress brought negative effects. Walther Rathenau warned about breaking the relationship between man and nature and the growing threat to ecology. Speaking about the active intervention of man in the 'workshop of Nature', he disputed the devastation, ruining and pollution of the environment, which could adversely affect many areas of human life. On a business trip to Africa in 1907, he urged the government to stop deforestation in East and South West Africa ${ }^{23}$.

Rathenau associated the most severe consequences with the onset of 'mechanization', which led to total changes in spiritual, social, economic and political life ${ }^{24}$. Man was caught in the web of organizations and institutions. According to Walther Rathenau's precise remark, the process of standardization at all levels of life began because of mechanical life-forms that represented a man's life going around in circles. A person changed into a machine, as after work, a mechanized person cannot engage in

\footnotetext{
${ }^{23}$ Schölzel C. Walther Rathenau. Eine Biographie, S. 75-80.

${ }^{24}$ Brenner W. Walther Rathenau. Deutscher und Jude, S. 287-292.
} 
creative work; he is focused only at himself, seeking to compensate the monotonous, mechanized labor with joy from the luxury of possession, the desire for pleasures and honors. A man became the mass, the man of 'profit' and an individualist. "Money intoxicate the weak and lead to enslavement.", Walter Rathenau wrote, "Since everything could be bought for money, there comes the dangerous depreciation of social relations $^{25}$.

With the growth of human wants, there appeared an imminent danger for human existence, for a human soul which "fell into a crush". Rathenau proposed the only way, in his opinion, to break the vicious circle - following the Christian moral code as the basis of acting ethically in business. For him, Christ was an example of humility, love for enemies and universal love. The logical consequence of such reasoning was the proclamation of Love as the highest earthly value, the sovereign good, the highest virtue and the supreme power. This was the force, in the opinion of Rathenau, which would help outface "I want to create and to be" over "I want to have". At the same time, what the soul wants - to create and to be - is intended not only for oneself but also for the society; and not only for the growth of personal wealth but also achieving the goal of universal happiness. The result of Rathenau's reasoning would be as follows: man and society should aspire "to the empire of the soul".

Rathenau developed the concept of the "empire of the soul" and the "empire of peace and love". It included several provisions:

1) industrial growth and material well-being; resource saving and curbing unemployment; production curtailment for luxury goods; free competition and growth of private initiative; readiness for people to bear responsibility;

2 ) the pursuance of money accumulation and excessive wealth as manifestation of evil;

3) overriding the rigorous ranking of classes;

4) creation of the conditions by the state to establish balance between classes and equal distribution of wealth ${ }^{26}$.

At first Rathenau believed that only liberalism, the new liberal policy, which he understood to be economy, free trade, anti-imperialism, freedom, justice and solidarity, could make Germany a great industrial power. Rathenau became liberal in politics under his parents' influence, who supported the liberal traditions of the revolutionary events in Prussia in 1848. He was disillusioned with the left-wing liberals and sympathized with the right-wingers. He was going to stand for election to the Reichstag, but for some reason he gave up the idea. After the end of World War I, in November

${ }^{25}$ Rathenau W. Zur Physiologie der Geschäfte. Rathenau W. Briefe. Neue Folge. Bd. 4. Dresden, 1928, S. 309 ff.

${ }^{26}$ Rathenau W. Gesammelte Schriften. Bde. 1-6, Bd. 3. Berlin, 1929, S. 151. 
Research

1918, Walter Rathenau attempted to create a "democratic people's union", but it existed only for a few days, as he accused, especially by Siemens, of orchestration of the social revolution. He joined the German Democratic Party (GDP), whose members, whilst recognizing the economic and socio-political program of Walter Rathenau, were arguing against him as a person. The documents say that he, a wealthy man, was seen, first, as a 'sponsor' of the party ${ }^{27}$. Ultimately, he concluded that liberalism could not contribute to the renewal of the society. His rhetoric on liberalism dated 1920 and stated not only the crisis of this political trend but also foretold the fate of traditional liberalism in the $20^{\text {th }}$ century. "The house that stands today is still an old house with its right and left wings, however this is not the home of the social future" 28 .

Responsibility, solidarity and democracy were the basis for changing society, in Rathenau's opinion. He opposed the dogmatic socialism, believing that the greed of the socialists was fading confronted by the stone-hearted classes in power. For Rathenau, property and the right of claim were not just a private matter: they were closely interrelated with the notion of "res publica". If one is to consider that Rathenau was one of wealthy entrepreneurs in Germany, his proposals stated in the book 'In Days to Come' (German: 'Von kommenden Dingen') are obviously of altruistic nature: "the society should ask what requirements it can put forward on behalf of the supreme law, and the economy uses what remains and what is necessary to maintain the mechanism and a decent way of life for its supervisors" ${ }^{29}$. Rathenau believed that "in the state, a 'parasitic state' appeared, as the state "caring about everyone and assimilating all people becomes a bureaucratic authority that does not provide a person with the main thing - the affection intended for them personally." Rathenau proposed to change the functional duties of the state: "We do not need the state that regulates and governs all, however the state which, in accordance with the principles of welfare, generously recognizes and supports the initiatives emanating from various social forces and combining the principle of voluntarism with active compassion and people in need of help" ${ }^{\text {30. }}$.

Rathenau was not a socialist, however, owning millions, he advocated fair distribution, which was the demand of the philanthropist to 'moralize' the inherited wealth. All his activities proceeded from the concept of "moralizing the public economic order, which is to obey the law on personal freedom",31, which caused irritation

${ }^{27}$ Rathenau W. Demokratische Entwicklung. Vortrag im Demokratischen Klub zu Berlin am 28. Juni 1920.

${ }^{28}$ Rathenau W. Gesammelte Schriften. Bde. 1-6. Bd. 3. Berlin Verlag Fischer, 1929, S. 51.

${ }^{29}$ Rathenau W. Von kommenden Dingen. Berlin, 1917, S. 85.

${ }^{30}$ Ibid.

${ }^{31}$ Ibid, S. 79. 
and caustic protest. A letter to Walter Rathenau from Heinghich Zellner, director of the state chemical laboratory in Berlin can be an example illustrating this: "You want to be a mentor for the German people, you preach morality, ethics and sacrifice ... How does this all relate to the fact that you own millions and millions, sit in many supervisory boards and without much effort and achievements, where all profit goes into their pockets? ... Can you only imagine, with what feelings we read your books and articles? ... If you want to impress us, then dispose of most of your fortune! Only then will I be ready and able to give you the right to improve our people, myself included"32. The newspaper Republik dated $19^{\text {th }}$ December 1918 called him "the modern Francis of Assisi, the most paradoxical of all living beings of Old Germany"33. And yet we must admit that, despite their utopian nature, Walther Rathenau's views were undoubtedly humanistic.

From the very beginning, Rathenau considered the global change in the context of the universal system. The process of mechanization changed not only the inner world of man, but, according to Walther Rathenau, it alienated people from one another on the international arena and promoted the growth of nationalism. Rathenau wrote, "People have never been so close to each other, never in their life they needed as much communication with each other, however nationalism is on the rise" ${ }^{\prime 34}$. The nationalism existed along with the economic policy and the war-readiness. The initial sympathy for militarism and imperialism was further rejected by Rathenau. Although he was not a pacifist, after 1911 he appealed to stop the arms race, supporting the plans of Theobald von Bettmann Hollweg, Chancellor of Germany, to conclude an agreement with England on setting limits to weapons. The rivalry was aggravated by Germany's claim to reinforce the navy forces. Since 1913, he urged the German government to stop the arms race and carry out the reforms. He considered the imperialist methods of foreign policy and the military leadership to be obsolete ${ }^{35}$.

Rathenau considered the outbreak of World War I to be the consequence of the 'cancerous tumor'. In August 1914, he suggested that the outcome of the war would be a new life, different from the old one, but stronger and deeper; however, "the ori-

${ }^{32}$ Rozhanskii L. "Ia khochu srazu otkryto zaiavit', chto ia - evrei..." ["I want to declare immediately and openly that I am a Jew ..."]. Kaskad [Cascade], $22^{\text {nd }}$ November 2012. Available at: http://kackad.com/kackad. (retrieved: 25.01.2018)

33 Schulin E. Walter Rathenau. Repräsentant, Kritiker und Opfer seiner Zeit. Göttingen; Zürich, 1992, S. 98.

${ }^{34}$ Rathenau W. Zur Kritik der Zeit. Rathenau W. Gesammelte Schriften. Bde. 1-6. Bd. 1. Berlin, 1929, S. 114.

${ }^{35}$ Hecker G. Walther Rathenau und sein Verhältnis zu Militär und Krieg. Boppard am Rhein, 1983. 
Research

gin of such life will be difficult and time-consuming"36. Walter Rathenau considered it necessary to offer his civil services to Theobald von Bettmann Hollweg to end the war sooner and create an integrated free-trade zone between Germany, AustriaHungary, Belgium and France. This proposal on the economic unity of Central (Middle) Europe was not followed by the government's response. The second proposal to arrange the delivery of military resources to Germany from the occupied territories - was supported, and Erich Georg Anton von Falkenhayn, the Chief of the German General Staff put Rathenau in charge of the Raw Materials Department of the War Ministry $^{37}$. Despite accusations against Rathenau for the conflict of interests affecting the War Ministry and $A E G$ and for his Jewish origin, he worked successfully, whilst implementing the new idea - the state regulation of the economy. In a difficult situation related to the supply of raw materials to Germany in times of war, Rathenau put forward an idea in which he refused direct state coercion to meet the needs of the military industry and tried to combine the state administration with the industrial selfgovernment. As a result, during the War Years in Germany, the interaction structure between the state and industrial enterprises, which was later called the "militaryeconomic system', was formed ${ }^{38}$.

After World War I, the name of Walther Rathenau was on the list of convicted war criminals. But, according to Rathenau, his goal was to achieve the world of mutual understanding. "If I have not thought about it, I would not have undertaken the organization for raw materials" 39 . He believed that if the military equilibrium was established between Germany and England, this would involve the battle fatigue, due to which it would be possible to hold peace negotiations between the equal partners. The German General Erich Ludendorff, the supporter of unrestricted submarine warfare, did not want to know anything about Rathenau's plan, considering it similar to the plan of the German Social Democratic politician Philipp Schneiderman who appealed to conclude peace of 'mutual understanding'.

After World War I, Walther Rathenau feared a new war, believing that the situation after the First World War was more like war than peace. In the current situation, he denied the state and violence as the driving forces for the social development but saw these in self-government and self-regulation: "We do not need the state anymore

${ }^{36}$ Rathenau W. Briefe, Bd. 1, S. 157.

${ }^{37}$ Schölzel C. Walther Rathenau. Eine Biographie, S. 172-197.

${ }^{38}$ Sadovaia G.M. Germaniia: ot kaizerovskoi imperii k demokraticheskoi respublike (19141922 gg.) [Germany: from the German (Kaiser) Empire to the German Democratic Republic (19141922)]. Samara, 2008, pp. 109-131.

${ }^{39}$ Beek J. van. Walther Rathenau (1867-1922), S. 98. 
... What we need ... is a self-governing, public society" "40. He considered the basic elements to achieve political unity in the world to be building of the society with integrated economics.

If one is to replace the concept of 'non-national' used by Walther Rathenau with that of 'supranational', it becomes clear what Rathenau meant by that word. 'Supranational' meant eliminating the national-level differences for him. He was realistic enough to expect a new world order built on such principles soon: "Decades will pass before this system of the international community is rebuilt" ${ }^{\text {"41 }}$. The thoughts expressed were premature (1920). Many knew Walther Rathenau, however did not understand him, taking him for a 'Trojan horse': initiating the establishment of the War Raw Materials Department (KRA), chairman of $A E G$, a capitalist, a socialist and the reform figure in economics.

Between 1921 and 1922, whilst being appointed Minister of Reconstruction, and then when he became Foreign Minister, Walther Rathenau participated in the most important international conferences, where World War II reparations were discussed $^{42}$. The Nationalist Forces of Germany considered his participation in the conferences in Spa and London "a game of international Jewish capital". However, Walther Rathenau "was not playing", he was considering his own conception, the content of which was defined in peace settlement for Germany, which, from his point of view, influenced the fate of Europe and the world, overall. "The Treaty of Versailles dismembers and destroys not only Europe .... It is accountable for the economic division of the world" "43. Therefore, criticizing The Treaty of Versailles and advocating the policy of 'implementation', Walther Rathenau worked intensively to plan the international conferences to restore Europe and Germany with the participation of Russia $^{44}$. His aim was to teach the European countries to trust each other and cooperate within an economic union; political unity, in his opinion, would come later, prompted by reducing conflicts and emerging solidarity. He believed that the integration of Europe had to be supplemented by the integration of all countries of the world, "with the unity and solidarity of the human community". In this international

${ }^{40}$ Rathenau W. Demokratische Entwicklung. Vortrag im Demokratischen Klub zu Berlin am 28. Juni 1920. Rathenau W. Gesammelte Schriften. Bd. 1-6. Bd. 3. Berlin, 1929, S. 51.

${ }^{41}$ Rathenau W. An Deutschlands Jugend. Rathenau W. Briefe. Neue Folge. Bd. 6. Dresden, 1928. Available at: http://gutenberg.spiegel.de/buch/an-deutschlands-jugend-4460/1. (retrieved: 25.01.2018)

${ }^{42}$ Hentzschel-Fröhlings J. Walther Rathenau als Politiker der Weimarer Republik. Husum, 2007.

${ }^{43}$ Rathenau W. Rede in einer Versammlung des Badischen Landesverbandes der DeutschDemokratischen Jugend. Gesammelte Reden. Mannheim, 1921, S. 280-281.

${ }^{44}$ Koenen G. Die "Völkerwanderung von unten": Walther Rathenau über Russland und Sowjets. Deutschland und Russische Revolution. 1917-1924. München, 1998, S. 240-274. 
Research

arena, he paid specific attention to the economic cooperation between Germany and Russia $^{45}$.

Rathenau "thought deeply patriotically in the spirit of the time as a German Jew" ${ }^{\prime 4}$, however the nationalists regarded the move as the betrayal of German interests. On $24^{\text {th }}$ June 1922 , Walter Rathenau was assassinated ${ }^{47}$, becoming a victim of the epoch ${ }^{48}$. The West German researcher Ernst Schulin made an interesting remark that Walter Rathenau was looking for his place in the world throughout his life, and the circumstances of his death made his life meaningful ${ }^{49}$. The epigraph on the website of the Rathenau Institute, a public knowledge organization (created in 2008), reads: "I want self-determination, self-deserving gaiety and freedom" (German: Ich will selbbestimmung, selb verdiendes Geshick und Freiheit $)^{50}$. Indeed, this was the way of life and life journey as determined by Rathenau himself, one-loner due to his otherness. The work helped Rathenau to cope with the depression and overcome suicidal thoughts. The door of his house in the villa in Grunewald was narrow, like the doorway to his soul, as he wanted us to avoid worming ourselves into another confidence $^{51}$. He remained a person by himself in the field of innovative ideas and a sociopolitical 'outsider' (German: Außenseiter).

Two years after the assassination of Walther Rathenau, the advisory board of the Walther Rathenau Institute was established ${ }^{52}$. Speaking at its opening, its chairman Friedrich Ebert was not only in favor of preserving the home and the property of Walther Rathenau but also wanted to change the facilities to develop spiritual and

${ }^{45}$ Pavlov N.V. Rossiia i Germaniia: nesostoiavshiisia al'ians (istoriia s prodolzheniem) [Russia and Germany: The Failed Alliance (a Continuation Story)]. Moscow, 2017, pp. 247-250.

${ }^{46}$ Hentzschel-Fröhlings J. Walther Rathenau als Politiker der Weimarer Republik, S. 291.

47 See Evdokimova T.V. Otkliki zarubezhnoi pressy na ubiistvo Val'tera Ratenau [Foreign press responses to the assassination of Walter Rathenau]. Lichnost', obshchestvo, kul'tura v istoricheskom protsesse: cbor. nauch. statei [Personality, Society, Culture in the Historical Process: Collection of Scientific Articles]. Volgograd, 2002, pp. 67-82; Idem. Ubiistvo Val'tera Ratenau i pervye otkliki na nego [Assassination of Walter Rathenau and the first reports of it]. Klio. Zhurnal dlia uchenykh [Klio. Journal for Scientists], 2003, no. 3(22), pp. 44-48.

${ }^{48}$ Sabrow M. Mord und Mythos. Das Komplott gegen Walther Rathenau 1922. Das Attentat in der Geschichte. Köln, 1996.

${ }^{49}$ Schulin E. Walter Rathenau. Repräsentant, Kritiker und Opfer seiner Zeit, S. 136.

${ }^{50}$ The Walter Rathenau Institute, an international policy foundation was established in 2008. S. Walther Rathenau Institut, Stiftung für internationale Politik. Available at: http: //www.rathenaustiftung.de. (retrieved: 25.01.2018)

${ }^{51}$ Petersen J. Utopiia prava [The law-based Utopia]. Lex Russica [Lex Russica], 2015, no. 2, p. 109.

52 S. Die WALTHER-RATHENAU-STIFTUNG e. V. Available at: http: // waltherrathenau.de/ueber-uns/walther-rathenau-stiftung-ev/ (retrieved: 25.01.2018) 
cultural ties, as well as provide open access to Rathenau's library and learning his $\operatorname{legacy}^{53}$.

\section{Conclusion}

In speaking of Walter Rathenau's legacy, Etta Feder-Kohlhaus ${ }^{54}$, one of the first authors on the works of Rathenau, enthusiastically called him "the first prophesier, the speaker of the new human epoch", "the guide, the leader to the "country of the soul", "the spark of divine genius that radiates through his works". However, if one is to remove the emotional coloring, the evaluative idealistic maximalism of her judgments and try to find a rational grain in them, one must agree that Rathenau "never rushed his thoughts and actions" and that "his works were characterized by creative and effective power".

Early in the $20^{\text {th }}$ century, he was interested in the biggest problems the humanity always faced and is facing today. Without using the term 'globalization', he took a stand for the creation of a European and international organization for cooperation, primarily in the economic sphere, which was implemented after World War II by the "founding fathers of the European Union". The modern European Union is an organization built on the principles of neo-liberalism, democracy and free-market economy. It partially corresponds to the concept of Walther Rathenau: rightly so from the point of view of economic and political aspects, however not from the social point of view. Europe and the world did not mirror the 'divine' Third Reich, the Reich 'struggling for the soul', where there is no place for selfishness and intolerance. In the words of Rathenau, the European societies have neither heart nor soul, however there is a nuclear threat, ecological problems, the demure social woes, migration crisis, the revival of nationalism and terrorism.

With the help of the term 'mechanization', Rathenau characterized the cultural and spiritual impoverishment of significant layers of the population at the turn of the $19^{\text {th }}$ and $20^{\text {th }}$ centuries, at the height of the industrial society. At the turn of the $20^{\text {th }}$ and $21^{\text {st }}$ centuries, in the information-oriented society, the human-factor problem as an addendum to the mechanisms, persisted, however now as related to the computers. The creative potential of the individual is compromised, and the importance of education and the state's responsibility is growing ever more acute: "If we are trying to save on the education of our youth", Rathenau wrote, "then we are serving not the soul and not the mind, however the fake economy"

${ }^{53}$ Ebert F. Schriften, Aufzeichnungen, Reden. Mit unveröffentlichten Erinnerungen aus dem Nachlass. Dresden, 1926, Bd. 2, S. 330-332.

${ }^{54}$ Feder-Kohlhaus M. Walther Rathenau. Sein Leben und Wirken. Dresden, 1928.

${ }^{55}$ Rathenau W. Nachgelassene Schriften. Zweiter Bd. Berlin, 1928, S. 362. 
Rathenau's important requirement was the one to expand the rights of an individual in all spheres of life, combined with the shared responsibilities. The protest movements of the late 1960s, starting with "Red May" in France in 1968, posed a serious challenge in the context of the shift in the Western world from 'material values' to 'post materialism'. New social movements of the 1970s-early 1980s (environmental movements, alternative frameworks, peace campaigns, etc.) demonstrated the readiness of a certain part of the society to solve the pressing problems on the principles of voluntarism, forcing the state to support their initiative.

Rathenau was not a socialist, but his ideas of state regulation of the economic sphere and that of a social state were continued with the emergence (in the 1930s) and development of 'social capitalism' with laissez-faire economic liberalism characterized by 'welfare' and the society of 'shared prosperity' (1950-60s).

Walter Rathenau could uncover the root causes of important modern processes. His own example revealed the human capabilities to see something new which is at its infancy, however beyond our perception; and, despite the futility of human efforts to go beyond the framework of usual and visible, to venture to be the first to travel the path. Only the integrity of the outlook, understanding the robust relationship of all vital processes and the encyclopedic knowledge equipped him to do so.

\section{References}

1. Akhtamzian A.A. Rapall'skaia politika. Sovetsko-germanskie diplomaticheskie otnosheniia v 1922-1932 gg. [Rapallo Politics. Soviet-German Diplomatic Relations in 1922-1932]. Moscow: Mezhdunarodnye otnosheniia [International Relations], 1974. 304 p. (In Russian)

2. Beek J. van. Walther Rathenau (1867-1922). Die Mission eines unverstandenen deutschjüdischen Europäers. Available at: www.beacruisesyeah.live/beuker/geschichte /texte_hefte/ Rathenaubuch. pdf 133 S. (retrieved: 25.01.2018)

3. Brenner W. Walther Rathenau. Deutscher und Jude. Cover: Walther Rathenau. München: Piper Verlag, 2005. $520 \mathrm{~S}$.

4. Craig G.F. Deutsche Staatskunst von Bismarck bis Adenauer. Düsseldorf: Droste Verlag, 1961. $168 \mathrm{~S}$.

5. Ebert F. Schriften, Aufzeichnungen, Reden. Mit unveröffentlichten Erinnerungen aus dem Nachlass. Dresden, 1926, Bd. 2, S. 330-332.

6. Evdokimova T.V. Otkliki zarubezhnoi pressy na ubiistvo Val'tera Ratenau [Foreign press responses to the assassination of Walter Rathenau]. Lichnost', obshchestvo, kul'tura $v$ istoricheskom protsesse: cbor. nauch. statei [Personality, Society, Culture in the Historical Process: Collection of Scientific Articles]. Volgograd: Peremena [Change], 2002, pp. 67-82. (In Russian)

7. Evdokimova T.V. Ubiistvo Val'tera Ratenau i pervye otkliki na nego [Assassination of Walter Rathenau and the first reports of it]. Klio. Zhurnal dlia uchenykh [Klio. Journal for Scientists], 2003, no. 3(22), pp. 44-48. (In Russian)

8. Feder-Kohlhaus M. Walther Rathenau. Sein Leben und Wirken. Dresden: Reissner, 1928. $309 \mathrm{~S}$. 
9. Gedenklauf für Walther Rathenau. Available at: https://www.lr-online.de/lausitz/ senftenberg/ gedenklauf-fuer-walther-rathenau_aid-3707586; Walther-Rathenau-Schule. Gymnasium https://www.wrs-berlin.de.(retrieved: 25.01.2018)

10. Grekov B.I. Val'ter Ratenau i Rossiia: evoliutsiia vneshnepoliticheskikh vzgliadov 19141922 [Walter Ratenau and Russia: The evolution of foreign policy views 1914-1922]. Pervaia mirovaia voina: diskussionnye problemy istoriiu [World War I: Controversial Issues in History]. Moscow: Nauka [Science], 1994, pp. 102-113. (In Russian)

11. Haffner S. Die Erinnerungen 1914-1933. Geschichte eines Deutschen. Deutsch. Stuttgart. München: Verlasg-Anstalt, 2001. 239 S.

12. Hecker G. Walther Rathenau und sein Verhältnis zu Militär und Krieg. Boppard am Rhein: Boldt, 1983. 542 S.

13. Hentzschel-Fröhlings J. Walther Rathenau als Politiker der Weimarer Republik. Husum: Matthiesen Verlag, 2007. 351 S.

14. Khaffner S. Biografiia odnogo nemtsa [The biography of one German]. Available at: https://unotices.com/book.php?id=83456\&page=8 (retrieved: 25.01 .2018$)$ (In Russian)

15. Koenen G. Die „Völkerwanderung von unten”: Walther Rathenau über Russland und Sowjets. Deutschland und Russische Revolution. 1917-1924. München: Wilhelm Fink Verlag, 1998, S. 240274.

16. Lypka T.I. Val'ter Ratenau i ego vremia: lichnost'v ekonomicheskoi, politicheskoi i intellektual'noi istorii Germanii kontsa XIX-pervoi treti XX v. [Walter Rathenau and his Time: A Person in the Economic, Political and Intellectual History of Germany at the end of the $19^{\text {th }}$ - first third of the $20^{\text {th }}$ century]. Kirov: ViatGU [Vyatka State University], 2008. 156 p. (In Russian)

17. Molodchik A.B. Sotsial'no-ekonomicheskie i politicheskie vzgliady i kontseptsii V. Ratenau: published summary of dissertation [Socio-economic and Political Views and Concepts V. Rathenau]. Perm, 2001. 26 p. (In Russian)

18. Pavlov N.V. Rossiia $i$ Germaniia: nesostoiavshiisia al'ians (istoriia s prodolzheniem) [Russia and Germany: The Failed Alliance (a Continuation Story)]. Moscow: Aspect Press [Aspect Press], 2017. 560 p. (In Russian)

19. Petersen I. Utopiia prava [The law-based Utopia]. Lex Russica [Lex Russica], 2015, no. 2, pp. 109-115. (In Russian)

20. Rathenau W. Briefe. Neue Folge. Bd. 4. Dresden, 1928.

21. Rathenau W. „Höre, Israel!” (1897). Dokumente - Gesellschaft und Kultur. S. 1. Available at: http://ghdi.ghi-dc.org/sub_document.cfm?document_id=717\&language=german (retrieved: 25.01.2018.)

22. Rathenau W. Gesammelte Schriften. Bde. 1-6. Bd. 5. Berlin: Fischer. Verlag, 1929. 456 S.

23. Rathenau W. Nachgelassene Schriften. Zweiter Bd. Berlin: S. Fischer. Verlag, 1928. $414 \mathrm{~S}$.

24. Rathenau W. Neue Briefe. Dresden, 1927.

25. Rathenau W. Tagebuch 1907-1922. Düsseldorf: Droste, 1967. 319 S.

26. Rathenau W. Gesammelte Schriften. Bde. 1-6. Bd. 1. Berlin, 1929. 345 S.

27. Rathenau W. Gesammelte Schriften. Bde. 1-6. Bd. 3. Berlin: Verlag Fischer, 1929. 366 S.

28. Rathenau W. An Deutschlands Jugend. Rathenau W. Briefe. Neue Folge. Bd. 6. Dresden, 1928. Available at: http://gutenberg.spiegel.de/buch/an-deutschlands-jugend-4460/1. (retrieved: 25.01.2018)

29. Rathenau W. Gesammelte Reden. Berlin: Verlag Fischer, 1924. 78 S. 
30. Rathenau W. Rede in einer Versammlung des Badischen Landesverbandes der DeutschDemokratischen Jugend. Gesammelte Reden. Mannheim, 1921. S. 280-281.

31. Rozhanskii L. "Ia khochu srazu otkryto zaiavit', chto ia - evrei..." ["I want to declare immediately and openly that I am a Jew ...”]. Kaskad [Cascade], $22^{\text {nd }}$ November 2012, Available at: http://kackad.com/kackad. (retrieved: 25.01.2018) (In Russian)

32. Sabrow M. Mord und Mythos. Das Komplott gegen Walther Rathenau 1922. Das Attentat in der Geschichte; hrsg. von A. Demandt. Köln: Böhlau, 1996, S. 321-344.

33. Sadovaia G.M. Germaniia: ot kaizerovskoi imperii $k$ demokraticheskoi respublike (19141922 gg.) [Germany: from the German (Kaiser) Empire to the German Democratic Republic (19141922)]. Samara: Samarskii universitet [Samara University], 2008. 273 p. (In Russian)

34. Schölzel C. Walther Rathenau. Eine Biographie. Paderborn: Ferdinand Schöning, 2006. $652 \mathrm{~S}$.

35. Schulin E. Walter Rathenau. Repräsentant, Kritiker und Opfer seiner Zeit. Göttingen, Zürich: Muster-Schmidt Verlag, 1992. 148 S.

36. Sontheimer M. Blitzende Gedankenfülle. Spiegel 25.09.12. Available at: http://www. spiegel.de/ spiegel/spiegelgeschichte/d-88536750.html (retrieved: 25.01.2018)

37. Tsveig S. Val'ter Ratenau. LEKhAIM OKTIaBR" 1999 KhEShVON 5760 - 10 (90) [LECHAIM OCTOBER 1999 HESHVON5760 - 10 (90)] Available at: https://lechaim.ru/ARHIV/ 90/cveyg.htm. (retrieved: 25.01.2018) (In Russian)

38. Volkov S. Ein jüdisches Leben in Deutschland 1867 bis 1922. München: Verlag Beck C.H., 2012. $250 \mathrm{~S}$.

39. Walther Rathenau - Symbolfigur der Republik. Allgemeine Zeitung. 23.09.2017. Available at: http://www.allgemeine-zeitung.de/vermischtes/leben-und-wissen/walther-rathenau-symbolfigurder-republik_18199565.htm. (retrieved: 25.01.2018)

For citation: Evdokimova T. Walter Rathenau - a man ahead of time. Historia provinciae - the journal of regional history, 2018, vol. 2, no. 2, pp. 14-29. DOI: $10.23859 / 2587-8352-2018-2-2-1$ 